\title{
Rekayasa Maturasi Menggunakan Hormon Oodev Terhadap Ikan Synodontis (Synodontis sp)
}

\author{
Maturation TechnicUsing Oodev Towards Catfish Synodontis (Synodontis sp.)
}

\author{
Yudha Lestira Dhewantara, Firsty Rahmatia \\ Program Studi Budidaya Perairan \\ Fakultas Perikanan dan Ilmu Kelautan USNI \\ e-mail* : yudhalestira@gmail.com
}

\begin{abstract}
Abstrak
Pematangan gonad merupakan salah satu fase penting pada siklus reproduksi ikan. Upaya hormonal memang bisa mempercepat proses pematangan dan pemijahan serta membantu pemijahan ikan yang sulit memijah bila tidak berada dalam habitatnya. Ikan synodontis memang mampu memijah sepanjang tahun. Namun, masalah yang muncul adalah kualitas hasil pemijahannya yang tidak selalu sama atau stabil, salah satu contoh hormon yang bisa digunakan adalah oodev yang mengandung Pregnant Mare Serum Gonadotropin (PMSG), hormon ini banyak mengandung unsur daya kerja Folicle Stimulating Hormone (FSH) yang berperan dalam pematangan gonad awal atau vitelogenesis. Penyerapan vitelogenin akan membuat oosit mencapai ukuran tertentu yang kemudian siap untuk diovulasikan. Penelitian ini bertujuan untuk mengkaji penyuntikan oodev terhadap kinerja reproduksi dan maturasi ikan synodontis. Calon induk ikan synodontis diberi perlakuan dengan injeksi hormonal dengan: K1 (tanpa pemberian hormon/kontrol), A1 (Dosis 0,5 mL/kg), A2 (Dosis $1 \mathrm{~mL} / \mathrm{kg}$ ), A3 (Dosis 1,5 $\mathrm{mL} / \mathrm{kg})$, dan A4 (2 mL/kg). Hasil penelitian menunjukkan bahwa Induksi maturasi ikan synodontis dapat dilakukan dengan penyuntikkan OODEV (1,5 mL/kg bobot tubuh) sebanyak empat kali secara berkala selama empat minggu.
\end{abstract}

Kata Kunci : Ikan Synodontis, Maturasi, Oodev

\begin{abstract}
Gonadal maturation is one of the important phases of the reproductive cycle of fish. Hormonal efforts can indeed accelerate the process of maturation and spawning, it helps spawn when it is not in their habitat. Synodontis fish is able to spawn throughout the year. However, the problem that arises is the quality of the nurseries which are not always the same, or stable, an example of hormone that can be used is oodev containing Pregnant Mare Serum Gonadotropin (PMSG), these hormones contain many elements working power folicle Stimulating Hormone (FSH), which play a role in the early gonad maturation or vitelogenesis. Absorption vitelogenin will make the oocyte reaches a certain size which is then ready for ovulation. This study aims to assess the performance of the injection oodev reproduction and maturation of fish Synodontis. Brood fish Synodontis treated with injections of hormonal with: K1 (without hormone / control), A1 (0,5 mL/ kg), A2 (1 mL/kg), A3 $(1,5 \mathrm{IU} / \mathrm{kg})$, and A4 ( $2 \mathrm{~mL} / \mathrm{kg})$. The results showed that the induction of maturation to do with Oodev injection $(1,5 \mathrm{~mL} / \mathrm{kg}$ body weight) four times at regular intervals for four weeks.
\end{abstract}

Keywords: fish Synodontis, maturation, oodev 


\section{Pendahuluan}

Pembenihan ikan merupakan salah satu bagian dari kegiatan budidaya. Pembenihan ikan dikatakan berhasil apabila produk yang dihasilkan tersedia secara kontinu dengan kualitas yang baik. Namun, masalah yang timbul di lapangan adalah adanya kesulitan memijahkan ikan atau mendapatkan benih berkualitas diluar musim pemijahan. Hal ini disebabkan karena ada kendala dalam proses pematangan gonad sepertiditemukannya ketidaksinkronan tingkat kematangan gonad antara induk jantan dan betina baik pada ikan perairan umum maupun yang dipelihara dalam lingkungan budidaya.Padahal sinkronisasi tingkat kematangan gonad, ovulasi dan pemijahan merupakan faktor yang menentukan dalam kontinuitas pengadaan benih (Rideout $e t$ $a l$, 2003). Karena apabila induk jantan dan betina tidak matang dalam waktu bersamaan, maka hasil pemijahan optimal tidak akan tercapai. Hal ini akan berdampak pada ketersediaan atau kontinuitas benih dengan kuantitas dan kualitas baik yang tidak akan terpenuhi.Sehingga perlu diupayakan strategi kontinuitasyang tepat waktu, tepat kualitas dan tepat harga (Zairin, 2003).

Salah satu solusi yang bisa dilakukan adalah dengan pendekatan hormonal.Upaya hormonal bisa mempercepat proses pematangan dan pemijahan serta membantu pemijahan ikan yang sulit memijah bila tidak berada dalam habitatnya (Sadili, 1996).Penerapan hormonal pada usaha budidaya ikanrelatif membutuhkan tingkat keterampilan yang tinggi (Sadili,1996; Widayawati, 1996).

Kematangan gonad ikan dapat dimanipulasi dan dipercepat dengan memberikan suntikan hormon dari luar sehingga ikan dapat memijah. Hal ini akan memberikan dampak pada peningkatan frekuensi pemijahan, reproduksi dapat diatur sesuai dengan yang diinginkan dan masa pematangan kembali (rematurasi) akan semakin pendek. Salah satu contoh hormon yang bisa digunakan adalah oodev yang mengandung Pregnant Mare Serum Gonadotropin (PMSG), hormon inibanyak mengandung unsur daya kerja Folicle Stimulating Hormone (FSH) yang berperan dalam pematangan gonad awal atau vitelogenesis. Penyerapan vitelogenin akan membuat oosit mencapai ukuran tertentu yang kemudian siap untuk diovulasikan.Jika pematangan gonad semakin cepat dan frekuensi pemijahan semakin sering maka kuantitas hasil reproduksi akan meningkat.

Oleh karena itu, pada penelitian ini dilakukan pengujian penggunaan Oodev terhadap ikan Synodontis yang bertujuan untuk mengkaji penyuntikan oodev terhadap kinerja reproduksi dan rematurasinya. Hasil dari penelitian ini diharapkan mampu memberikan kontribusi terhadap peningkatan produksi induk ikan synodontis sehingga benih berkualitas tersedia secara kontinu.

Ikan synodontismerupakan salah satu ikan hias yang banyak digemari dan diminati oleh para pecinta ikan. Hal ini mengindikasikan kebutuhan benih juga akan meningkat dari tahun ke tahun.Ikan synodontis memang mampu memijah sepanjang tahun. Namun, masalah yang muncul adalah kualitas hasil pemijahannya yang tidak selalu sama atau stabil. Ada masa dimana kinerja reproduksi seperti fekunditas, derajat tetas telur, diameter telur, dan kondisi larva tidak baik. Oleh karena itu, penelitian untuk menjaga kestabilan kualitas kinerja reproduksi perlu dilakukan.

\section{Bahan dan Metode}

\section{Waktu dan Tempat Penelitian}

Penelitian ini dilaksanakan di Balai Penelitian Dan Pengembangan Budidayalkan Hias (BPPBIH) Depok, Jawa Barat. Waktu penelitian dilaksanakan dari Bulan Maret - Mei 2016.

\section{Bahan dan Alat}

\section{Hewan Uji}

Induk ikan Synodontis yang digunakan berasal dari pembenih (breeder) daerah Bogor. Penelitian ini menggunakan induk yang sudah pernah memijah untuk dirematurasi. Penelitian ini akan dilakukan penyeragaman tingkat kematangan gonad. Setelah induk ikan mencapai kematangan gonad yang merata untuk siap pijah maka induk akan disuntik ovaprim (dosis $0,7 \mathrm{ml} / \mathrm{kg}$ induk) dan dicampur dengan induk jantan dengan perbandingan 1:1. Sekitar 12 jam setelah penyuntikan ovaprim, telur yang dikeluarkan induk dikumpulkan hingga tidak ada lagi telur yang tersisa. Beberapa ikan dari penelitian akan diambil untuk pengamatan histologi gonad. 
Hormon yang digunakan

Hormon yang digunakan adalah oodev yang mengandung hormon PMSG dan Anti dopamin. Dosis oodev yang diberikan adalah 0 $\mathrm{ml} / \mathrm{kg}, 0,5 \mathrm{ml} / \mathrm{kg}, 1 \mathrm{ml} / \mathrm{kg}, 1,5 \mathrm{ml} / \mathrm{kg}$, dan $2 \mathrm{ml} / \mathrm{kg}$.

\section{Perlakuan}

Rancangan penelitian yang digunakan adalah Rancangan Acak Lengkap (RAL) dan diulang sebanyak tiga kali, perlakuan yang diberikan pada penelitian ini adalah untuk calon induk. Perlakuan dapat disajikan melalui tabel di bawah ini.

Tabel 1. Perlakuan Penelitian

Table 1. Treatment Research

\begin{tabular}{llllll}
\hline Perlakuan & $\neq \mathrm{H}$ & $\mathrm{A} 1$ & $\mathrm{~A} 2$ & $\mathrm{~A} 3$ & $\mathrm{~A} 4$ \\
Dosis & $0 \mathrm{ml} / \mathrm{kg}$ & $0,5 \mathrm{ml} / \mathrm{kg}$ & $1 \mathrm{ml} / \mathrm{kg}$ & $1,5 \mathrm{ml} / \mathrm{kg}$ & $2 \mathrm{ml} / \mathrm{kg}$ \\
\hline
\end{tabular}

Keterangan :

$\mathrm{K} 1$ = Tanpa penyuntikan hormon

$\mathrm{A} 1=$ Penyuntikan hormon $0,5 \mathrm{ml} / \mathrm{kg}$,

$\mathrm{A} 2=$ Penyuntikan hormon $1 \mathrm{ml} / \mathrm{kg}$,

A3 $=$ Penyuntikan hormon $1,5 \mathrm{ml} / \mathrm{kg}$,

A4 =Penyuntikan hormon $2 \mathrm{ml} / \mathrm{kg}$,

\section{Wadah}

Wadah yang digunakan adalah berupa 15 buah akuarium masing-masing berukuran $40 \mathrm{~cm} \mathrm{x}$ $50 \mathrm{~cm} \times 30 \mathrm{~cm}$, Selain itu juga dipersiapkan bak pemijahan dengan ukuran $1 \mathrm{~m}$ x $2.5 \mathrm{~m}$. Induk yang telah matang gonad akan dipindahkan ke wadah pemijahan dan dipasangkan dengan induk jantan dengan perbandingan 1:1. Wadah lain yang digunakan adalah akuarium berukuran $40 \mathrm{~cm}$ x $50 \mathrm{~cm}$ x $30 \mathrm{~cm}$ sebanyak 15 buah untuk wadah inkubasi telur, penetasan, dan pemeliharaan larva.

\section{Metode Penelitian}

\section{Perlakuan}

Perlakuan pada penelitian tersaji dalam Tabel 1. Penyuntikan hormon dilakukan sebanyak 4 kali dengan interval selama 1 minggu. Selama pemeliharaan, ikan diberi makan dengan feeding rate sebesar 3\% dari bobot tubuhnya per hari. Frekuensi pemberian pakan yaitu 3 kali pada pukul 07.00, 12.00,dan 17.00 WIB.

Setiap perlakuan menggunakan satu akuariumdan tiap akuariumdiisi 1 ekor ikan. Sebanyak 3 ekor ikan akan diambil seekor pada awal, tengah, dan akhir penelitian untuk pengamatan histologi gonad serta analisis Gonadosomatik Indeks (GSI) Sedangkan 2 ekor ikan lainnya akan diamati kinerja reproduksinya, jumlah induk dijadikan sebagai ulangan.

\section{Parameter yang diamati}

Dalam penelitian ini, parameter yang akan diamati adalah sebagai berikut :

1) Diameter telur. Pengamatan dilakukan dengan menggunakan mikroskop yang dilengkapi mikrometer okuler dengan pembesaran $40 \times 10$.

2) Fekunditas relatif, diperoleh dengan menghitung jumlah telur yang dikeluarkan oleh setiap induk dalam satu kali pemijahan dan kemudian dibandingkan dengan kg bobot tubuhnya.

3) Derajat Tetas Telur (DTT), diperoleh dengan membandingkan jumlah telur yang menetas dengan telur yang ditetaskan.

$$
\operatorname{DTT}(\%)=\frac{\text { jumlah telur yang menetas }}{\text { jumlah telur yang ditetaskan }} \times 100 \%
$$

4) Survival rate larva $\left(\mathrm{SR}_{4}\right)$, perhitungan $\mathrm{SR}$ ini dilakukan sebanyak tiga kali dan hasilnya kemudian dirata-ratakan.

$\operatorname{SR}(\%)=\frac{\text { jmlh larva yg mampu hidup sampai } 4 \text { hari }}{\text { jumlah larva awal }} \times 100 \%$

5) Gonad Somatik Indeks (GSI)

$$
\text { GSI }=\frac{\text { bobot ovarium }}{\text { bobot tubuh ikan }} \times 100 \%
$$

\section{Pelaksanaan Penelitian}

Pelaksanaan penelitian dilakukan dengan metode yang sama. Sebelum induk ikan dimasukkan ke dalam akuarium pemeliharaan, 
dilakukan pemeriksaan akuarium dari kebocoran. Bila ternyata ada kebocoran maka akuariumterlebih dahulu diperbaiki. Akuarium kemudian diisi air dengan kedalaman $40 \mathrm{~cm}$. Jika ketinggian air berkurang maka akan dilakukan penambahan air ke dalam akuarium. Sebelum dilakukan percobaan, ikan uji diadaptasikan selama 1 minggu. Selama periode adaptasi, ikan diberi pakan kontrol dengan feeding rate (FR) 3\% bobot tubuh perhari. Ikan uji yang digunakan dalam penelitian ini ditandai secara individu (tagging) dengan menggunakan penanda yang berwarna dan bernomor yang diselipkan pada sirip punggung. Selama penelitian, ikan tersebut diberi pakan perlakuan 3 kali sehari dengan FR sebesar 3\% dari bobot tubuh. Pengukuran parameter kualitas air untuk suhu dilakukan setiap hari yaitu di pagi dan sore hari. Kandungan oksigen terlarut (DO) dan $\mathrm{pH}$ diukur sekali seminggu, sedangkan kandungan alkalinitas dan amonia diukur tiga kali, yaitu pada awal, tengah, dan akhir penelitian.

Pengamatan perkembangan gonad dilakukan setiap minggu bersamaan dengan waktu penyuntikan hormon. Setiap sampling dimulai dengan pembiusan ikan dengan menggunakan MS22, kemudian dilanjutkan dengan perendaman induk dalam larutan Elbazu. Setelah itu dilakukan penimbangan induk. Sebelum induk dimasukkan kembali ke dalam kolam, induk direndam kembali dalam larutan Elbazu untuk menghindari terjadinya luka. Induk yang tidak memijah di bedah guna dilakukan pengamatan histologi gonad. Pemeriksaan kematangan telur, induk yang telah matang gonad segera dipindahkan kebak lainuntuk persiapan pelaksanaan pemijahan semi alami. Pemijahan semi alami dilakukan dengan menyuntikkan ovaprim dosis $0.7 \mathrm{ml} / \mathrm{kg}$ secara intramuscular dan dicampur dengan induk jantan dengan perbandingan 1:1. Sekitar
10-12 jam setelah penyuntikan, dilakukan pengecekan induk untuk memijah. Kemudian telur yang dikeluarkan, dikumpulkan dan ditimbang. Sebanyak 100ml sampel telur diambil untuk penghitungan fekunditas relatif. Perhitungan fekunditas ini dilakukan sebanyak tiga kali dan nilai yang diperoleh kemudian dirata-ratakan. Sebanyak 200 butir dipindahkan ke akuarium inkubasi untuk diamati derajat penetasannya. Pemeliharaan larva tetap dilakukan di wadah penetasan hingga 4 hari setelah larva menetas. Jumlah larva yang masih hidup sampai dengan 4 hari pemeliharan kemudian dihitung untuk mendapatkan nilai survival rate $\left(\mathrm{SR}_{4}\right)$.

\section{Analisis Statistik}

Data dianalisis dengan analisis varian satu faktor (one-way ANOVA, $\mathrm{P}<0.05$ ). Perbedaan signifikan antara perlakuan dianalisis dengan menggunakanDuncan multiple range (DMR) test. Jika tidak terdapat perbedaan nyata $(\mathrm{P}>0.05)$ maka semua data akan dianalisis secara deskriptif dalam bentuk tabel dan gambar.

\section{Hasil dan Pembahasan}

\section{Gonad Somatik Indeks (GSI)}

Hasil pengamatan terhadap indeks kematangan gonad ikan synodontis pada awal pemeliharaan sebesar 1,18\%. Setelah 12 hari indeks kematangan gonad terjadipeningkatan (Tabel 3), dengan dosis $2 \mathrm{ml} / \mathrm{kg}$ ikan diperoleh nilai tertinggi danberbeda nyata $(\mathrm{P}<0,05)$ dengan dosis $0 \mathrm{ml} / \mathrm{kg}$ (kontrol) ikan dan $1,5 \mathrm{ml} / \mathrm{kg}$ ikan, namundosis $5 \mathrm{ml} / \mathrm{kg}$ ikan dan $1,5 \mathrm{ml} / \mathrm{kg}$ ikan tidak berbeda nyata $(\mathrm{P}>0,05)$ denganperlakuan dosis $0 \mathrm{ml}$ (kontrol) ikan dan 10 $\mathrm{ml} / \mathrm{kg}$ ikan. Pada hari ke-28 antarperlakuan diperoleh hasil yang sama $(\mathrm{P}>0,05)$. 
Tabel 2. Indeks kematangan gonad ikan synodontis

Table 2. fish gonad maturation index Synodontis

\begin{tabular}{ccc}
\hline Perlakuan & \multicolumn{2}{c}{ Tingkat Kematangan Gonad } \\
& H14 & H28 \\
\hline kontrol & 0 & 0 \\
$0,5 \mathrm{ml} / \mathrm{kg}$ & $5,21 \pm 1,04^{\mathrm{ab}}$ & $6,51 \pm 0,84^{\mathrm{a}}$ \\
$1 \mathrm{ml} / \mathrm{kg}$ & $3,59 \pm 0,43^{\mathrm{b}}$ & $6,04 \pm 1,13^{\mathrm{a}}$ \\
$1,5 \mathrm{ml} / \mathrm{kg}$ & $4,46 \pm 2,89^{\mathrm{ab}}$ & $7,45 \pm 0,71^{\mathrm{a}}$ \\
$2 \mathrm{ml} / \mathrm{kg}$ & $9,30 \pm 0,25^{\mathrm{a}}$ & $6,01 \pm 0,77^{\mathrm{a}}$
\end{tabular}

Angka pada kolom sama dengan huruf yang sama menunjukkan hasil tidak berbeda nyata $(\mathrm{P}>0,05)$ uji selang kepercayaan Tukey*) Sampling hari ke-14(H14), sampling hari ke$28(\mathrm{H} 28)$

Fekunditas, Fertilization Rate, Hatching Rate dan Survival Rate
Ikan synodontis yang telah diinduksi dengan hormon OODEV kemudian dipijahkan secara semi buatan dengan induksi ovulasi berupa hormon ovaprim.Kinerja reproduksi berupa fekunditas, fertilization rate, hatching rate dan survivalrate ikan betok pada induksi maturasi dengan hormon OODEV disajikan padaTabel 3.

Tabel 3. Kinerja reproduksi ikan synodontis pada induksi maturasi dengan hormon OODEV Table 3. Performance Synodontis fish reproduction on the induction of maturation with OODEV hormones

\begin{tabular}{cccccc}
\hline & kontrol & $0,5 \mathrm{ml}$ & $1 \mathrm{ml}$ & $1,5 \mathrm{ml}$ & $2 \mathrm{ml}$ \\
\hline Bobot & $47 \pm 6,0$ & $42 \pm 0,0$ & $44,5 \pm 4,5$ & $49 \pm 9,0$ & $37 \pm 3,0$ \\
$\begin{array}{c}\text { Induk memijah } \\
\text { Fekunditas } \\
\text { relatif (butir/g) }\end{array}$ & 0 & 100 & 100 & 100 & 100 \\
$\begin{array}{c}\text { Diameter telur } \\
\text { Derajat }\end{array}$ & 0 & $13.997 \pm 5205$ & $12.334 \pm 2440$ & $15.851 \pm 3879$ & $13.864 \pm 2670$ \\
$\begin{array}{c}\text { pembuahan (\%) } \\
\text { Derajat }\end{array}$ & 0 & $0.97 \pm 0.02$ & $0.99 \pm 0.01$ & $0.95 \pm 0.05$ & $0.98 \pm 0.02$ \\
$\begin{array}{c}\text { penetasan (\%) } \\
\text { Sintasan larva } \\
(\%)\end{array}$ & 0 & 92.6 & 98.32 & 99.42 & 79.59 \\
\hline
\end{tabular}

\section{Pembahasan}

Kegiatan pembenihan ikan synodontis berlangsung dalam waktu yang relatif singkat yaitu selama satu bulan untuk menghasilkan benih yang siap didederkan untuk kegiatan pembesaran. Pada musim kemarau induk ikan synodontis yang telah dipijahkan, dapat dipijahkan kembali dan matang gonad setelah 3 bulan sampai 4 bulan. Waktu pematangan 
gonad induk relatif lebih lama dibandingkan dengan siklus pemeliharaan larva, sehingga ketersediaan induk matang gonad tersebut dapat menghambat siklus pembenihan selanjutnya. Untuk mempercepat kematangan gonad induk ikan synodontis yang telah dipijahkan dapat dilakukan dengan rangsangan hormonal yaitu pemberian OODEV. Hal ini dapat dilihat keberhasilannya melalui pengamatan nilai indeks kematangan gonad dan tingkat kematangan gonad. Hasil indeks kematangan gonad tertera pada Tabel 2, bahwa setelah 14 hari terjadi peningkatan nilai indeks kematangan gonad dan tertinggi pada dosis 2 $\mathrm{ml} / \mathrm{kg}$ ikan sebesar 9,30 $\pm 0,25$. Dengan demikian, pemberian hormon OODEV memberikan pengaruh terhadap indeks kematangan gonad induk ikan synodontis dan dapat mempercepat kematangan gonad dengan 2 kali penyuntikan. Sotolu dan Kigbu (2011) menyatakan bahwa pada stadia induk, gizi difokuskan untuk kebutuhan perkembangan gonad ikan betina.

Kandungan PMSG dalam hormon OODEV yang digunakan adalah $1 \mathrm{ml} / \mathrm{kg}$. Setelah 24 hari dengan 4 kali penyuntikan dengan hormon OODEV, indeks kematangan gonad mengalami peningkatan dan menunjukkan hasil yang sama $(\mathrm{P}>0,05)$ (Tabel 2$)$, namun pada dosis $2 \mathrm{ml} / \mathrm{kg}$ ikan sebesar $6,01 \pm 0,77 \%$ mengalami penurunan. Hal ini diduga pada hari ke-14 indeks kematangan gonad telah mencapai nilai yang maksimum sebesar 9,30 $\pm 0,25 \%$ dan siap untuk dipijahkan, namun apabila tidak dipijahkan, telur akan mengalami atresia atau penyerapan telur kembali.

Menurut Effendie (1994) nilai indeks kematangan gonad merupakan perubahan yang terjadi di dalam gonad secara kuantitatif dan meningkatnya nilai indeks kematangan gonad sejalan dengan perkembangan kematangan gonad. Sesuai dengan hasil pengamatan bahwa pada hari ke-14 diperoleh nilai indeks kematangan gonad tertinggi pada dosis $2 \mathrm{ml} / \mathrm{kg}$ ikan dan sejalan dengan tingkat kematangan gonad telah mencapai stadia IV. TKG IV. Dengan demikian, pemberian hormon OODEV mampu mempercepat kematangan gonad ikan synodontis. OODEV mengandung hormon PMSG dan AD. Hormon PMSG mengandung aktivitas seperti FSH dan LH. Hormon ini bekerja cenderung lebih banyak seperti FSH untuk pematangan gonad awal, sedangkan LH berperan dalam merangsang proses kematangan gonad yang kemudian siap untuk diovulasikan (Farastuti dkk 2014). Menurut Nagahama et al. (1991) hormon PMSG pada ikan medaka dapat meningkatkan produksi estradiol 17ß. Estradiol 17ß berperan sebagai stimulator dalam biosintesis vitelogenin yang diproduksi oleh lapisan granulosa di bawah pengaruh gonadotropin. Menurut Tang dan Affandi (2004) mekanisme kerja gonadotropin hormon (GTH) dalam mempercepat pematangan gonad yaitu GTH I (FSH) akan bekerja pada sel-sel teka dan menghasilkan testosteron, kemudian pada sel-sel granulosa oleh enzim aromatase akan dikonversi menjadi estradiol 17ß. Estradiol 17ß dibawa ke hati untuk merangsang sintesis vitelogenin yang berperan dalam proses vitelogenesis, sehingga memicu perkembangan oosit semakin besar sampai fase dorman dan menunggu sinyal lingkungan lain yang melepaskan GTH II (LH) dan berperan dalam terjadinya pematangan dan ovulasi. AD berfungsi untuk menghambat kerja dopamin dan dopamin berfungsi untuk menghambat sekresi GnRH. Ketika diamati pada minggu ke-0 dengan metode kanulasi serta pembedahan sebanyak lima ekor induk perlakuan, maka terlihat bahwa induk belum matang gonad. Hal tersebut ditandai dengan perut yang masih kosong, lubang kelamin yang belum memerah, dan tidak terdapat telur saat dikanulasi.

Setelah perlakuan selama 2 minggu, kemudian dilakukan pembedahan kembali dan didapatkan hasil ikan mulai bunting. Kebuntingan ditandai dengan bagian perut induk yang terasa lembek serta lubang urogenital yang memerah danbengkak. Setiap perlakuan menghasilkan tingkat kematangan gonad (TKG) yangberbeda pula. Induk yang bunting tersebut tidak semuanya menghasilkan teluryang siap dibuahi karena belum mencapai kematangan sempurna.

Pemijahan induk ikan synodontis yang telah diberikan hormon OODEV dilakukan pada hari ke-30 dan dilakukan pemijahan secara buatan. Saat kegiatan pemijahan induk jantan yang telah matang gonad sulit didapatkan, sehingga dapat menjadi kendala dalam kegiatan pembenihan walaupun induk betina yang matang gonad telah tersedia. Berdasarkan hasil pengamatan induk betina yang sebelumnya dilakukan pematangan gonad dengan hormon OODEV dapat memijah $100 \%$, sedangkan induk yang tanpa pemberian hormon OODEV tidak dapat memijah. Hal ini disebabkan karena oosit belum siap untuk 
diovulasikan dan kematangan oosit masih pada stadia TKG I.

Fekunditas yang dihasilkan sama $(\mathrm{P}>0,05)$ pada semua perlakuan yaitu berkisar 12.334$15.851 \mathrm{butir} / \mathrm{g}$ induk. Hal ini disebabkan pada penelitian ini dilakukan dalam wadah terkontrol serta menurut Rahmatia dkk (2013) faktor yang mempengaruhi fekunditas diantaranya suhu, karena semakin tinggi suhu maka jumlah fekunditas akan semakin meningkat. Fertilization rate diperoleh nilai tertinggi pada dosis $1,5 \mathrm{ml} / \mathrm{kg}$ ikan yang berbeda nyata $(\mathrm{P}<0,05)$ terhadap perlakuan kontrol, namun menunjukan hasil yang sama $(\mathrm{P}>0,05)$ dengan perlakuan dosis hormon OODEV yang lainnya. Dengan demikian, induksi rematurasi hormon OODEV dapat mempengaruhi kualitas pembuahan terhadap telur. Menurut Tang dan Affandi (2004), fertilisasi adalah proses bergabungnya inti sperma dan inti sel telur yang akan membentuk zigot. Menurut Burmansyah et al. (2013), faktor yang mempengaruhi derajat pembuahan adalah kualitas telur dan kualitas sperma. Hasil penelitian Zalina et al., (2012), menunjukkan bahwa persentase penetasan telur ikan betok yang diberikan perlakuan hormon LHRH-a sebanyak $20 \mu \mathrm{g} / \mathrm{kg}$ bobot tubuh menghasilkan persentase penetasan tertinggi yaitu 68,57 $73,11 \%$.Hatching rate dan survivalrate tertera pada Tabel 3, menunjukkan hasil yang sama ( $P>0,05)$, sehingga induksi rematurasi dengan hormon OODEV tidak menurunkan hasil kinerja reproduksi ikan synodontis.

\section{Simpulan}

Kesimpulan yang diperoleh yaitu hormon OODEV dengan dosis $1,5 \mathrm{ml} / \mathrm{kg}$ ikan merupakan dosis terbaik untuk mempercepat pematangan gonad pada ikan synodontis.

\section{Ucapan Terima Kasih}

Saya ucapkan terima kasih kepada RISTEKDIKTI yang membiayai penelitian ini dalam program Hibah Dosen Pemula, Balai Penelitian dan Pengembangan Budidaya Ikan Hias-Depok yang telah memfasilitasi penelitian ini sampai selesai.

\section{Daftar Pustaka}

Burmansyah, Muslim, dan M. Fitrani. 2013. Pemijahan Ikan Betok (Anabas testudineus) Semi Alami dengan
SexRatio Berbeda. Jurnal Akuakultur Rawa Indonesia, 1(1) :23-33.

Chumaidi., Sudarto., A. Priyadi., Kusdiarti., dan P. Yuliati. 2006. Teknik Budidaya Ikan Balashark (Balantiocheilus melanopterus) : Penangkaran dan Pembenihan. Makalah Seminar Nasional Ikan Hias Nusantara.Taman Mini Akuarium Air Tawar 9 Desember 2006.

Farastuti ER, Sudrajat AO, dan R Gustiano 2014. Induksi maturasi gonad, ovulasi dan pemijahan pada ikan tor soro (Tor soro) menggunakan kombinasi hormon.Jurnal LIMNOTEK 201421 (1) : 87-94

Nagahama Y, Matsuhisa A, Iwamatsu T, Sakai N, Fukada S. 1991. A mechanism for the action of pregnant mare serum gonadotripin on aromatase activity in the ovarian follicle of the medaka, Oryzias latipes. Journal of Experimental Zoology. 259:53-58.

Rahmatia F, Utomo NBP, AO Sudrajat. 2013. Pengaruh Kombinasi Penambahan Spirulina Platensis Pada Pakan dan Penyuntikan Hormon PMSG Terhadap Reproduksi Ikan Nila. Jurnal OLDI 201339 (3): 321-328

Rideout, R.M., M.K.Litvak and E.A. Trippel. 2003.The Development of A Sperm Cryopreservation Protocol For Winter Flounder Pseudopleuronectes americanus (Walbaum) : Evalution of Cryopreservation and Diluents. Aquaculture Research 34 : 653-659.

Setiyaningrum, N. dan A. Nuryanto. 2006. Penjinakan dan dan Budidaya Ikan Brek (Puntius orphoides) Sebagai Upaya Diversifikasi Usaha Tani Ikan. Jurnal Pembangunan Pedesaan 6 (3) : 46-54.

Sotolu AO, Kigbu AA. 2011. Growth and gonad quality of Clarias gariepinus(Burchell, 1822) broodstock fed varying dietary protein levels. ProductionAgriculture and Technology. 7(2): 61-67.

Tang U M. dan R Affandi. 2000. Biologi reproduksi ikan. Fakultas Perikanan dan Ilmu. Kelautan. IPB. Bogor. Bogor. 150 hal. 
Yudha Lestira Dhewantara :Rekayasa Maturasi Menggunakan Hormon Oodev Terhadap Ikan Synodontis (Synodontis sp)

Zairin, M. 2003. Endokrinologi Dan Perannya Bagi Masa Depan Perikanan Indonesia. Orasi Ilmiah Guru Besar. Fakultas Perikanan dan ilmu Kelautan. Institut Pertanian Bogor. Bogor.

Zalina, I., C.R. Saad., Christianus, dan S.A.

Harmin. 2012. Induced Breeding and
Embryonic Development Of Climbing Perch (Anabas testudineus). Department of Aquaculture, Faculty Of Agriculture Universiti Putra Malaysia. Selangor. Journal of Fisheries and Acuatic Science 7(5) : 291306. 